\title{
Kids and Condoms: Parental Involvement in School Condom-Distribution Programs
}

\author{
Miranda Perry $\dagger$
}

To counter the growing number of teenagers infected with the HIV virus, almost four hundred public junior high and high schools nationwide, including those in New York, Washington, D.C., and Philadelphia, have begun distributing condoms to students. ${ }^{1}$ When the New York City public school system began its program in 1991, it neither required prior parental consent nor gave concerned parents a chance to "opt out." In Alfonso $v$ Fernandez, a New York state appellate court ruled that such a program, by entirely bypassing parents, violated the parents' right to control the upbringing of their children. ${ }^{3}$ The court remarked that it would allow distribution if New York permitted parents to opt out of the program, ${ }^{4}$ but the court's opinion did not address the more stringent alternative of requiring prior parental consent. Since then, in Curtis $v$ School Committee of Falmouth, the Massachusetts Supreme Judicial Court held that parental involvement in such programs is not constitutionally required. ${ }^{5}$ Hence, it is unclear whether parental involvement in public-school condom-distribution programs is necessary, and if so, what form such involvement should take. This Comment argues that parental involvement is constitutionally mandated, and, further, that condom-distribution programs requiring prior parental consent are the only such programs adequately protective of parental rights to withstand constitutional scrutiny.

The Supreme Court has long recognized that, under the Due Process Clause of the Fourteenth Amendment, ${ }^{6}$ parents have a

† B.A. 1993, Duke University; J.D. Candidate 1996, The University of Chicago.

1 See Douglas J. Besharov, Life is Not Just a Bowl of Condoms, Wash Post C1, C4 (May 1, 1994) (Washington, DC); Alfonso v Fernandez, 195 AD2d 46, 606 NYS2d 259, 261 (1993) (New York); Parents United for Better Schools, Inc. $v$ School Dist. of Philadelphia $B d$ of Educ., 166 Pa Commw 462, 646 A2d 689, 690 (1994) (Philadelphia).

2 Both courts and schools use "opt out" as a verb to refer to the ability of a parent to excuse his or her child from an undesirable school program, and "opt-out provisions" to refer to excusal provisions.

3195 AD2d 46, 606 NYS2d 259, 265 (1993).

4 Id at 267.

5420 Mass 749, 652 NE2d 580, 586 (1995), cert denied, 116 S Ct 753 (1996).

6 "No State shall ... deprive any person of life, liberty, or property, without due pro- 
constitutionally protected liberty interest in directing their children's upbringing and education. ${ }^{7}$ Like other recognized liberty interests, however, this parental right is not absolute. ${ }^{8}$ But because the right is grounded in the Due Process Clause of the Fourteenth Amendment and considered fundamental, limitations of parental liberty should be strictly scrutinized. ${ }^{9}$ Hence, a state regulation should be allowed to limit parents' rights only if the infringement is both necessary and narrowly tailored to promote a compelling government interest. ${ }^{10}$

When schools distribute condoms, some parents feel their liberty interests are burdened. These parents sense an invasion because they feel that schools-to which they are obligated by law to send their children-implicitly condone sexual activity by providing children with the means to engage in it more safely. While parents share control over a child's education and upbringing with the state, some parents may feel that the state's encouragement of an activity that they oppose crosses the line between supplementing parental guidance and supplanting it. Hence, condom-distribution programs in schools, and their attendant invasion of the parental liberty interest, should be strictly scruti-

cess of law ...." US Const, Amend XIV, $\S 1$.

7 The Court has interpreted the right of parents to direct the rearing of their children to come under the constitutional auspices of the fundamental right to privacy guaranteed by the Fourteenth Amendment. See Carey $v$ Population Services International, 431 US 678, 684-85 (1977). Earlier cases, while finding that parents had a "liberty interest" in the raising of their children protected by the Fourteenth Amendment, did not couch this interest in the terms of a fundamental right to privacy. See Meyer $v$ Nebraska, 262 US 390,400 (1923) (The right of parents to direct the education of their children is "within the liberty of the [Fourteenth] Amendment."); Pierce $v$ Society of Sisters, 268 US 510, 53435 (1925) (A statute prohibiting private education "unreasonably interferes with the liberty of parents and guardians to direct the upbringing and education of children under their control."); Prince v Massachusetts, 321 US 158, 166 (1944) ("It is cardinal with us that the custody, care and nurture of the child reside first in the parents, whose primary function and freedom include preparation for obligations the state can neither supply nor hinder.").

${ }^{8}$ Prince, 321 US at 166 ("[T]he family itself is not beyond regulation in the public interest.").

9 Ronald D. Rotunda and John E. Nowak, 2 Treatise on Constitutional Law: Substance and Procedure $\S 15.7$ at 434-36 (West $2 \mathrm{~d}$ ed 1992). Both equal protection and due process analysis employ the strict scrutiny standard of review when regulations or classifications affect the exercise of fundamental rights. See id $\S 15.4$ at 401-02; Ronald D. Rotunda and John E. Nowak, 3 Treatise on Constitutional Law: Substance and Procedure $\S 18.3$ at $15-16$ (West $2 \mathrm{~d}$ ed 1992). Thus, this Comment often uses examples from the equal protection context to illuminate its application in the due process context.

${ }_{10}$ See, for example, Alfonso, 606 NYS2d at 265. See also Michael $v$ Hertzler, 900 P2d 1144, 1145 (Wyo 1995) (holding that because parental rights are fundamental, statute permitting grandparents to bring action to obtain rights visit to grandchildren requires strict scrutiny). 
nized by the courts; that is, they should be upheld only when the infringements are narrowly tailored to meet a compelling state interest."

There is no legal dispute that preventing Acquired Immune Deficiency Syndrome ("AIDS") ${ }^{12}$ is a compelling state interest, and the provision of AIDS education seems both a necessary ${ }^{13}$ and a narrowly tailored means of meeting that goal. The cases do not settle, however, the issue of when condom-distribution programs, as opposed to educational programs, also meet these criteria.

Because of the burden that such programs impose on those parents who do not want the school to facilitate their children's sexual activity, many feel that only programs granting parents final authority over whether their children may obtain condoms are acceptable. Moreover, the issue of parental involvement in school condom programs is further complicated because different forms of parental involvement can result in markedly disparate outcomes, with concomitantly varying levels of intrusion on parental rights. For example, opt-out provisions place the burden on parents to act affirmatively to reclaim their legal authority from the state in order to prevent their children from receiving condoms at school. In contrast, prior consent requirements leave this authority with the parents until they affirmatively delegate it to school officials by authorizing their children's participation in the condom-distribution program. In strict scrutiny terms, these distinctions are relevant to whether a program is sufficiently "narrowly tailored." As an increasing number of school systems across the country contemplate condom-distribution

11 Rotunda and Nowak, 2 Treatise on Constitutional Law $\$ 15.4$ at 402 (cited in note 9). See also Reno $v$ Flores, 507 US 292, 302 (1993) ("[T]o infringe certain 'fundamental' liberty interests ... the infringement [must be] narrowly tailored to serve a compelling state interest.") (citations omitted). Courts often apply strict scrutiny without explicitly so stating. As a general rule, though, if a court is looking for a compelling state interest to justify a government regulation, it is applying strict scrutiny. See Rotunda and Nowak, 3 Treatise on Constitutional Law $\S 18.3$ at 15 (cited in note 9).

${ }_{12}$ The spread of AIDS has been the impetus for condom-distribution programs. Historically, the prevention of teen pregnancy and venereal disease have justified sex education courses and the provision of contraceptives to minors. Today, AIDS is also mentioned as a justification. See, for example, Alfonso, 606 NYS2d at 263; Stephen Buckley, Sex Education's Tough Question, Wash Post D1, D1, D3 (Feb 28, 1994). For the traditional case for sex education in the public schools, see Fernand N. Dutile, Sex, Schools and the Law 48-49 (Thomas 1986).

${ }^{13}$ See Ware $v$ Valley Stream High School District, 75 NY2d 114, 551 NYS2d 167, 176 (1989) ("Education regarding the means by which AIDS is communicated is a powerful weapon against the spread of the disease and clearly an essential component of our nationwide struggle to combat it."). 
plans, ${ }^{14}$ the question of what level of parental involvement-if any-is required deserves careful attention.

This Comment analyzes whether school ${ }^{15}$ condom-distribution programs should be subject to strict scrutiny, and if so, how such programs should be structured to withstand this heightened standard of review. Section I examines the general right of parents to influence the upbringing and education of their children and emphasizes its grounding in the Due Process Clause of the Fourteenth Amendment. Section II demonstrates why condom distribution at school presents a unique problem unresolved by current law. It addresses the Alfonso and Curtis decisions, which not only contradict each other but also fail to address the full range of legal issues involved in school distribution programs. This Section also compares such programs to sex education courses and nonschool condom-distribution programs. Although precedent from these contexts does not address all the issues that arise when schools distribute condoms to students, it nonetheless illuminates the scope of the parental liberty interest. Finally, Section III argues that public-school condom-distribution programs should be reviewed under a standard of strict scrutiny and concludes that only those programs that require prior parental consent should be constitutionally permissible.

\section{THE Right OF PARENTS TO INFLUENCE THE UPBRINGING AND EDUCATION OF THEIR CHILDREN}

\section{A. The Origins of the Parental Liberty Interest}

In a trilogy of cases in the 1920s, the Supreme Court established that parents have a constitutionally protected liberty interest in directing their children's upbringing and education. ${ }^{16}$ In all three cases, the Court explicitly grounded this liberty in the Due Process Clause of the Fourteenth Amendment. ${ }^{17}$ The three cases also suggest that, although it is not absolute, the parental liberty interest they establish is at least immune from arbitrary and unreasonable interference. ${ }^{18}$

14 See Buckley, Sex Education's Tough Question, Wash Post at D7 (cited in note 12); Chastity Pratt, Superintendent Balks at Condom Distribution Idea, Wash Post Md Weekly 1, 7 (July 14, 1994).

15 Throughout this Comment, "school" refers only to public schools.

${ }^{16}$ See Meyer $v$ Nebraska, 262 US 390 (1923); Pierce $v$ Society of Sisters, 268 US 510 (1925); Farrington $v$ Tokushige, 273 US 284 (1927).

${ }_{17}$ Meyer, 262 US at 399-400; Pierce, 268 US at 534-35; Farrington, 273 US at 298-99.

18 Meyer, 262 US at 399-400 ("[T] $]$ his liberty may not be interfered with . . . by legisla- 
In Meyer $v$ Nebraska, the first of the trilogy, a schoolteacher challenged his conviction for teaching German to a ten-year-old boy in violation of a statute that prohibited teaching foreign languages to students before the eighth grade. ${ }^{19}$ The Court held that the statute "unreasonably infringe[d] the liberty guaranteed... by the Fourteenth Amendment" by interfering with both the teacher's right to teach German and, more importantly, the boy's parents' right to hire a teacher to do so. ${ }^{20}$ In reaching this conclusion, the Court recognized that the exact scope of the liberty protected by the Fourteenth Amendment was undefined, but listed a number of rights included in the Amendment:

Without doubt, it denotes not merely freedom from bodily restraint but also the right of the individual to contract, to engage in any of the common occupations of life, to acquire useful knowledge, to marry, establish a home and bring up children, to worship God according to the dictates of his own conscience, and generally to enjoy those privileges long recognized at common law as essential to the orderly pursuit of happiness by free men. ${ }^{21}$

Thus, in finding the Nebraska law unconstitutional, the Court first recognized parents' Fourteenth Amendment right to influence and direct their children's upbringing and education.

Two years later, in Pierce $v$ Society of Sisters, ${ }^{22}$ the Court made an even stronger statement about the liberty interest it recognized in Meyer. The Pierce Court held unconstitutional an Oregon law that mandated that all children attend public school, thereby preventing parents from sending their children to private or parochial schools. ${ }^{23}$ Specifically referring to the Meyer doctrine, the Court found it "entirely plain that the [Oregon law] ... unreasonably interferes with the liberty of parents and guardians to direct the upbringing and education of children

tive action which is arbitrary or without reasonable relation to some purpose within the competency of the State to effect."); Pierce, 268 US at 535 ("[R]ights guaranteed by the Constitution may not be abridged by legislation which has no reasonable relation to some purpose within the competency of the State."); Farrington, 273 US at 298 ("The [ ] parent has the right to direct the education of his own child without unreasonable restrictions.").

19 262 US 390, 396-97 (1923).

20 Id at 399, 402.

21 Id at 399.

22268 US 510 (1925).

${ }^{23}$ Id at 536. 
under their control."24 The Court then addressed the balance of interests between parents and the state in influencing child development, stating that "[t]he child is not the mere creature of the State; those who nurture him and direct his destiny have the right, coupled with the high duty, to recognize and prepare him for additional obligations."25

In Farrington $v$ Tokushige, the last of the 1920s trilogy, the Court invalidated a Hawaiian statute that regulated almost every aspect of private schooling. ${ }^{26}$ In particular, the statute effectively banned private after-school classes that were taught in Japanese and the subject matter of which included, among other things, Japanese language and culture. ${ }^{27}$ Citing Meyer and Pierce, the Court held that the law unreasonably interfered with the parents' ability to direct and control the upbringing of their children by denying them the opportunity to teach their children Japanese. ${ }^{28}$

These three cases, all involving parental challenges to state attempts to monopolize education, establish that the state must allow parents some control to augment and direct their children's education. ${ }^{29}$ They do not, however, address what steps parents can take to prevent the state from encroaching on the parental domain by conducting programs that disrupt educational functions-teaching about religion and sexuality, for example-traditionally left to the family.

In Wisconsin $v$ Yoder, ${ }^{30}$ the Supreme Court began to grapple with whether parents may object to state educational programs because they undermine traditionally parent-initiated education. In that case, Amish parents objected to a statute making school attendance mandatory until age sixteen on the grounds that it violated their First Amendment right to the free exercise of religion. The Amish parents argued that because mandatory attendance "takes [children] away from their community, physically and emotionally, during the crucial and formative adolescent period of life,"31 it "was contrary to the Amish religion and way

24 Id at 534-35.

25 Id at 535.

26273 US 284, 298-99 (1927).

27 Id at 298.

28 Id at 298-99.

29 For an overview of the scope of judicially recognized parental rights to influence the public school education of their children, see generally Ralph D. Mawdsley, Parental Rights and Public Education, 59 Educ L Rptr 271 (1990).

30406 US 205 (1972).

31 Id at 211. 
of life," and thereby jeopardized both their children's salvation and their own. ${ }^{32}$ The Court agreed, recognizing that the statute interfered with the free exercise of the Amish religion. ${ }^{33}$

Although it ruled on free exercise grounds, the Yoder Court also reaffirmed the importance of parental liberty:

[T]he history and culture of Western civilization reflect a strong tradition of parental concern for the nurture and upbringing of their children. This primary role of the parents in the upbringing of their children is now established beyond debate as an enduring American tradition. ${ }^{34}$

In reinforcing the pro-parents' rights stance undertaken in Pierce, the Court noted that the "additional obligations" for which the Pierce Court held parents must prepare their children "must be read to include the inculcation of moral standards, religious beliefs, and elements of good citizenship."35

At a minimum, Yoder suggests that parents may object to state educational activities that directly undermine parent-initiated religious education. Unfortunately, Yoder does not illuminate when parents may object to state programs that threaten nonreligious parental education initiatives. Although the Court made it clear that parents may lodge such objections under the First Amendment only when they are religiously based, ${ }^{36}$ nothing in its decision states that parents could not ground nonreligious objections to state programs in other parts of the Constitution. Moreover, the Yoder Court's analysis of Pierce is somewhat misleading. For example, it read into Pierce the specific right to direct the religious upbringing of one's child; then, it recast that right as grounded in the Free Exercise Clause. It seems, however, to have left untouched Pierce's more general holding that parents enjoy the right to direct the education and upbringing of their children as part of the substantive due process guaranteed by the Fourteenth Amendment.

The Supreme Court has been quite clear, however, that the state's own interests also matter, and in some cases justify the limitation of certain parental prerogatives, whether religiously grounded or not. In Prince $v$ Massachusetts, the Court first artic- 
ulated such a limitation when it upheld a state child-labor law against a hybrid free exercise-parental liberty challenge. ${ }^{37}$ In that case, the guardian of a nine-year-old girl objected to a law that prevented the girl from selling magazines for the Jehovah's Witnesses. The guardian argued that the law prevented her from raising the child as she desired, including teaching the child the practices of her religion, and thus violated both her free exercise right and her parental liberty interest. ${ }^{38}$

The Prince Court rejected this argument, using the same analysis for both types of rights. It held that:

[N]either rights of religion nor rights of parenthood are beyond limitation. Acting to guard the general interest in youth's well being, the state as parens patriae may restrict the parent's control by requiring school attendance, regulating or prohibiting the child's labor, and in many other ways. $^{39}$

In reaching this conclusion, the Court balanced the state's interest in protecting children from employment against the rights of parents to exercise their religion and to raise their children accordingly..$^{40}$ In giving precedence to the state's interest, Prince clearly established that the state may regulate certain parental activities, regardless of whether parents claim protection under the Fourteenth Amendment parental liberty interest or the First Amendment right to the free exercise of religion.

Although Prince limits the parental liberty interest recognized in Pierce, Meyer, Farrington, and Yoder, today's parents undeniably continue to enjoy a substantial liberty interest in directing their children's upbringing and education. This interest limits certain state educational activities, such as those depriving parents' choice concerning their children's educational experiences. The state, however, enjoys similar interests that can limit parental activity in certain situations, and the tension between the competing interests of the parents and the state often gives rise to litigation.

${ }^{40}$ Id at 168-70. 


\section{B. The Modern Contours of the Parental Liberty Interest}

Unfortunately, the precise scope of the parental liberty interest in today's world of more activist government remains unclear. Traditionally, the law has established certain boundaries to limit both the state and parents. The state could not completely deprive parents of the ability to shape their children's education; ${ }^{41}$ nor could parents completely exclude the state from their children's education..$^{42}$ As the state begins to provide more of the guidance traditionally supplied by parents, however, new boundaries will have to be established between the rights of parents and the powers of the state. The controversy surrounding condom distribution in the schools illustrates the tension and uncertainty one encounters at the edges of these boundaries.

Existing case law does little to define these boundaries. The early cases establishing the parental liberty interest-Pierce, Meyer, and Farrington-date from a period when the Court used a "reasonable relation" test to evaluate legislation under the doctrine of substantive due process. ${ }^{43}$ Subsequent cases refining the scope of parental liberty-Prince and Yoder-mix parental liberty claims with free exercise claims, subjecting both to the heightened scrutiny applied to free exercise claims. ${ }^{4}$

Most importantly, because the Court analyzed the claims in Yoder under the First Amendment, it did not determine which of the current standards of review-rational relation, intermediate scrutiny, or strict scrutiny ${ }^{45}$-would apply to a due pro-

41 See Meyer, 262 US at 400; Pierce, 268 US at 534-35; Farrington, 273 US at 298.

12 Yoder, 406 US at 234 (Amish children still required to attend school through junior high); Care and Protection of Charles, 399 Mass 324, 504 NE2d 592, 598 (1987) (State may require parents to obtain approval prior to home schooling their children.).

43 Meyer, 262 US at 403 ("We are constrained to conclude that the statute as applied is arbitrary and without reasonable relation to any end within the competency of the State.") (emphasis added); Pierce, 268 US at 535 (" $[R]$ ights guaranteed by the Constitution may not be abridged by legislation which has no reasonable relation to some purpose within the competency of the State.") (emphasis added); Farrington, 273 US at 298 (speaking of "unreasonable restrictions"). For a discussion of these cases, see Rotunda and Nowak, 2 Treatise on Constitutional Law $\S 15.3$ at 389 (cited in note 9).

* Prince, 321 US at 170 (finding a child labor law "necessary to accomplish its legitimate objectives") (emphasis added); Yoder, 406 US at 215 ("[O]nly those interests of the highest order and those not otherwise served can overbalance legitimate claims to the free exercise of religion."). Whether heightened scrutiny still applies to neutral and generally applicable laws in the free exercise context remains unclear. See Employment Division $v$ Smith, 494 US 872, 881-82 (1990) (holding that the Free Exercise Clause alone does not bar "the application of a neutral, generally applicable law to religiously motivated action"). But see Religious Freedom Restoration Act of 1993, Pub L No 103-141, 107 Stat 1488 , codified at 42 USC $\S 2000 \mathrm{bb}$ (1994) (attempting to reinstate Yoder's application of strict scrutiny to neutral, generally applicable laws).

15 For a general discussion of the standards of review used in the due process and 
cess-based parental liberty claim. This is especially significant because Yoder is the modern case most squarely addressing the liberty interest in rearing one's child; hence the Court has never directly resolved which standard of review would apply to a claim grounded in that interest. By continually acknowledging the importance of parental control and guidance, ${ }^{46}$ and by referring to it as part of the right to privacy protected by the Fourteenth Amendment, ${ }^{47}$ however, the Court suggests that strict scrutiny is the appropriate standard.

This suggestion stems from the Court's recognition of the right to privacy as a "fundamental" right. Such rights include not only most of those enumerated in the first eight amendments of the Bill of Rights, ${ }^{48}$ but also a narrow list of nonenumerated rights that the Court has chosen to protect even though the Constitution itself does not mention them. ${ }^{49}$ To limit this list, the

equal protection contexts, see Rotunda and Nowak, 3 Treatise on Constitutional Law $\S$ 18.3 at $12-41$ (cited in note 9).

${ }_{46}$ See, for example, H.L. $v$ Matheson, 450 US 398, 410 (1981) ("We have recognized that parents have an important 'guiding role' to play in the upbringing of their children, ... which presumptively includes counseling them on important decisions.") (citations omitted); Quilloin $v$ Walcott, 434 US 246, 255 (1978) ("We have recognized on numerous occasions that the relationship between parent and child is constitutionally protected.") (citations omitted); Ginsberg v New York, 390 US 629, 639 (1968) (' $[C]$ onstitutional interpretation has consistently recognized that the parents' claim to authority in their own household to direct the rearing of their children is basic in the structure of our society.").

${ }^{47}$ See, for example, Planned Parenthood $v$ Casey, 505 US 833, 851 (1992) ("Our law affords constitutional protection to personal decisions relating to ... family relationships, child rearing, and education. .. . These matters, involving the most intimate and personal choices a person may make in a lifetime, choices central to personal dignity and autonomy, are central to the liberty protected by the Fourteenth Amendment.") (citations omitted); Bellotti $v$ Baird, 443 US 622, 637, 639 n 18 (1979) (plurality opinion) (exploring the "guiding role of parents in the upbringing of their children" and noting that "Pierce, Yoder [and] Prince ... all have contributed to a line of decisions suggesting the existence of a constitutional parental right against undue, adverse interference by the State"); Roe $v$ Wade, 410 US 113, 152-53 (1973) (noting that only personal rights deemed "fundamental" or "implicit in the concept of ordered liberty" are included in the right of privacy and stating that this right extends to family relationships and child rearing and education); Moore $v$ City of East Cleveland, 431 US 494, 499 (1977) (explaining that Meyer, Pierce, and their progeny establish a "private realm of family life" that is one of the "liberties protected by the Due Process Clause of the Fourteenth Amendment").

${ }_{48}$ See Rotunda and Nowak, 2 Treatise on Constitutional Law § 15.6 at $418-27$ (cited in note 9); Casey, 505 US at 847 ("The most familiar of the substantive liberties protected by the Fourteenth Amendment are those recognized by the Bill of Rights.").

${ }_{49}$ See Casey, 505 US at 847-49 (noting that the Bill of Rights does not mark "the outer limits of the substantive sphere of liberty which the Fourteenth Amendment protects"); Bowers v Hardwick, 478 US 186, 191 (1986) (noting that Meyer, Prince, and Pierce recognized fundamental "rights that have little or no textual support in the constitutional language"). 
Court requires that a nonenumerated right be not only "implicit in the concept of ordered liberty," but also one "traditionally protected by our society" before recognizing it as fundamental. ${ }^{50}$ Because these are malleable concepts, though, the Court is understandably reluctant to find that a given right meets these standards. ${ }^{51}$

Once the Court deems a right to be fundamental, however, it requires that state regulations infringing that right withstand strict scrutiny. ${ }^{52}$ Such regulations must therefore serve a compelling state interest and be narrowly tailored to meet that interest. ${ }^{53}$ When the Court refers to the parental liberty interest as part of the recognized fundamental right to privacy, it thus implicitly casts parental liberty as a fundamental right. ${ }^{54}$ By so doing, the Court implies (though it has never held) that infringements on the parental liberty interest must withstand strict scrutiny.

Although lower federal and state courts agree that the parental liberty interest is fundamental and that infringements of it merit strict scrutiny, these courts do not automatically cast all parental activities as fundamental. Hence, courts do not apply strict scrutiny to every regulation that affects parenting, but rather only to state regulations that impede specific parental activities.

so Michael H. $v$ Gerald D., 491 US 110, 122 (1989) ("In an attempt to limit and guide interpretation of the Clause, we have insisted not merely that the interest denominated as a 'iberty' be 'fundamental,' . . . but also that it be an interest traditionally protected by our society."); Hardwick, 478 US at 192 (declining to recognize a "fundamental right [of] homosexuals to engage in acts of consensual sodomy"); Roe, 410 US at 152 ("[O]nly personal rights that can be deemed 'fundamental' or 'implicit in the concept of ordered liberty' are included in [the Fourteenth Amendment's] guarantee of personal privacy.") (citations omitted).

${ }^{51}$ See Collins $v$ City of Harker Heights, 503 US 115, 125 (1992) (discussing the restraint required when the Court analyzes a fundamental rights claim); Hardwick, 478 US at 194 (declining "to take a more expansive view of [the Court's] authority to discover new fundamental rights imbedded in the Due Process Clause"); Michael H., 491 US at 122 (noting that "the Court should be extremely reluctant to breathe still further substantive content into the Due Process Clause").

${ }_{52}$ Rotunda and Nowak, 2 Treatise on Constitutional Law $\$ 15.7$ at 427 (cited in note 9); Reno $v$ Flores, 507 US 292, 302 (1993) (Government may not infringe upon a fundamental liberty interest "unless the infringement is narrowly tailored to serve a compelling state interest.") (citations omitted).

${ }_{53}$ Rotunda and Nowak, 2 Treatise on Constitutional Law $\S 15.4$ at 402 (cited in note 9); Flores, 507 US at 302.

st Rotunda and Nowak, 2 Treatise on Constitutional Law $\$ 15.7$ at 436 (cited in note 9) ("[T] $]$ here is a fundamental right to privacy which . . . has been held to include rights to freedom of choice ... in child-rearing."). 
For example, several state courts have refused to use strict scrutiny to analyze parental challenges to home schooling regulations ${ }^{55}$ thereby implicitly refusing to cast home schooling as a "fundamental" parental right. Conversely, lower federal and state courts have found that parental liberty interests could be considered fundamental in relation to the dispensation of birth control to minors, implying that strict scrutiny should be applied where such interests are burdened. ${ }^{56}$ This characterization suggests that educating one's child about sexuality falls within the scope of the protected liberty interest. The fact that the Supreme Court itself has cast other activities relating to the creation and sustenance of families as fundamental ${ }^{57}$ buttresses the notion that influencing one's child's sexual upbringing is a "fundamental" right.

By any standard, then, neither the state nor a child's parents can monopolize the child's education. The Fourteenth Amendment guarantees to parents some ability to control their children's upbringing. What remains unclear, however, is the extent to which this liberty interest enables parents to protest when the state does not overtly restrict parental choice but in-

${ }_{55}$ See Charles, 504 NE2d at 599 (upholding prior approval requirement for home schooling as not violating parents' "basic" right to educate children); State $v$ DeLaBruere, $154 \mathrm{Vt} 237,577 \mathrm{A2d} 254,274$ (1990) (“[P]arents' rights must give way to reasonable state regulation.") (emphasis added); Murphy $v$ Arkansas, 852 F2d 1039, 1043 (8th Cir 1988) (finding in home schooling context "no persuasive arguments ... that there is a fundamental right of parents to supervise their children's education.... Thus, again, strict scrutiny cannot be invoked in this case."). See also Joseph P. Tocco, Note, Home Schooling in Michigan: Is There a Fundamental Right to Teach Your Children at Home?, $71 \mathrm{U}$ Detroit Mercy L Rev 1053, 1060 n 55 (1994) (collecting cases).

${ }^{56}$ Doe $v$ Irwin, 615 F2d 1162, 1167-69 (6th Cir 1980) (implying that had the court found an interference with "plaintiffs' rights as parents," it would have applied strict scrutiny by considering "whether a 'compelling state interest' was involved"); Curtis, 652 NE2d at 585-86 (agreeing that "parents possess a fundamental liberty interest" in child rearing but holding that voluntary nature of condom distribution did not interfere with this interest and hence inquiry into the state's interest was unnecessary); Alfonso, 606 NYS2d at 266-67 (holding school condom-distribution program unnecessary to meet compelling state interest and hence a violation of parents' "rights to direct the upbringing of their children"). While all three cases agree that strict scrutiny should be applied where parental rights are impaired, they differ over exactly what constitutes an impairment.

57 See Griswold $v$ Connecticut, 381 US 479, 485 (1965) (contraception); Loving $v$ Virginia, 388 US 1, 12 (1967) (marriage); Moore, 431 US at 503 (living arrangements); Yoder, 406 US at 233 (religious education of children). Together, these rights suggest a "private realm of family life" protected from state interference. Moore, 431 US at 499. Logically, if the state's ability to regulate individuals' decisions about entering and starting families is limited, so too should its ability to regulate those activities that many parents view as one of the major functions of the family-such as transmitting values and attitudes about the aforementioned activities-be limited. See Stephen Gilles, On Educating Children: A Parentalist Manifesto, $63 \mathrm{U}$ Chi L Rev (forthcoming 1996). 
stead supplements and supplants what has traditionally been taught at home. The scope of the interest will likely turn on the specific nature of what the parents are teaching at home. Something as important and private as sexuality, however, should enable parents to invoke the parental liberty interest and its attendant strict scrutiny.

\section{School Condom-Distribution Programs AND THE PARENTAL LIBERTY INTEREST}

Currently, almost four hundred schools nationwide distribute condoms to students. ${ }^{58}$ Most programs exist in large cities, where concerns over AIDS and teen pregnancy are highest. ${ }^{59}$ Despite sharing the same justification for dispensing condoms, schools vary in the ways they have chosen to structure their programs. ${ }^{60}$ Schools that distribute condoms generally structure their programs in one of three ways. They can distribute condoms on demand without any parental involvement, distribute them only to students whose parents previously consented to their participation in the program, or distribute them to any student except those whose parents have opted them out of the program. Of schools currently distributing condoms, 39 percent do not involve parents at all, ${ }^{61} 21$ percent require prior parental consent, and 41 percent allow parents to opt their children out. ${ }^{62} \mathrm{~A}$ school district's choice regarding the extent of parental in-

ss Besharov, Life is Not Just a Bowl of Condoms, Wash Post at C4 (cited in note 1).

59 See Deborah Rissing Baurac, Teen sex: Condom distribution still a volatile policy issue, Chi Trib Womanews 1 (Sept 20, 1992) (reporting that most of the schools that distribute condoms are in major urban areas such as New York, Chicago, Los Angeles, Philadelphia, and Dallas); Eugene C. Bjorklun, Condom Distribution in the Public Schools: Is Parental Consent Required?, 91 Educ L Rptr 11, 13 (1994) (noting that condom-distribution programs "are almost entirely concentrated in the largest districts in the nation in the Northeast and on the West Coast where there is more concern about HIV/AIDS transmission than in other parts of the country").

60 Bjorklun, 91 Educ L Rptr at 14-15 (cited in note 59).

${ }^{61}$ Most such programs do require some adult participation, such as counseling from the school's health clinic. In New York City's program, for example, trained health professionals dispensed the condoms in "health resource" rooms established for that purpose. These professionals then counseled students requesting condoms on their proper use and the consequences of their use or misuse. See Alfonso, 606 NYS2d at 261.

62 Bjorklun, 91 Educ L Rptr at 15 (cited in note 59). For a more complete description of New York's program, which is representative of programs containing opt-out clauses, see Karl J. Sanders, Comment, Kids and Condoms: Constitutional Challenges to the Distribution of Condoms in Public Schools, 61 U Cin L Rev 1479, 1488-90 (1993). 
volvement, if any, will generally affect the number of students who participate in its program. ${ }^{63}$

\section{A. Alfonso and Curtis: Inconsistent and Incomplete}

To date, only New York and Massachusetts courts have addressed the Fourteenth Amendment parental liberty implications of schools distributing condoms. ${ }^{64}$ Not only do the two cases contradict each other, but they fail to address adequately all the issues raised by condom-distribution programs. The resulting precedent leaves schools that desire to implement such programs unsure about how to proceed. ${ }^{65}$

A group of New York parents was the first to contest in court the distribution of condoms at their children's schools. In Alfonso, concerned parents challenged the New York City public school system's condom-distribution program, which neither required prior parental consent nor gave concerned parents a chance to opt out. ${ }^{66}$ The parents leveled three distinct charges. First, they argued that the program violated their right to consent to the provision of health services to their children. ${ }^{67}$ Second, the parents maintained that the program violated their Fourteenth Amendment parental-liberty interests. ${ }^{68}$ And finally, the parents contended that the program infringed their First Amendment free exercise rights. ${ }^{69} \mathrm{~A}$ New York appellate court readily agreed

63 Bjorklun, 91 Educ L Rptr at 15 (cited in note 59).

${ }^{64}$ See Alfonso, 606 NYS2d at 265; Curtis, 652 NE2d at 584. Parents in Philadelphia are currently litigating a similar, though distinct, issue. In Parents United for Better Schools, Inc. $v$ School Dist. of Philadelphia Bd of Educ., $166 \mathrm{~Pa}$ Commw 462, 646 A2d $689,690-91$ (1994), parents have argued that the distribution of condoms constitutes "health services," and they are basing their challenge on the common law right of parents to consent to the provision of medical services to their children.

${ }_{65}$ Commentators have likewise been silent. Although a score of articles analyzes parental consent requirements in the contexts of sex education, abortion, and access to birth control at nonschool clinics, only three discuss access to birth control devices in public school clinics. See Marcia Mobilia Boumil, Dispensing Birth Control in Public Schools: Do Parents Have a Right to Know?, 18 Seton Hall L Rev 356 (1988) (analyzing whether parental involvement is necessary at all); Bjorklun, 91 Educ L Rptr 11 (cited in note 59) (same); Sanders, Comment, 61 U Cin L Rev 1479 (cited in note 62) (same). Each of these basically mimics the Alfonso court by analyzing the question whether parental involvement is needed at all; only one examines how parental involvement should be structured when such programs do attempt to involve parents. Sanders, Comment, $61 \mathrm{U}$ Cin L Rev at 1510-13 (cited in note 62) (generally endorsing opt-out plan as a wise decision on the part of administrators planning distribution programs).

66606 NYS2d at 261.

67 Id at 262.

Es Id at 265 .

69 Id at 267. 
with the health-service claim, ${ }^{70}$ but disagreed with the free exercise claim. ${ }^{71}$

The court's analysis of the parental liberty claim is significant for two reasons. First, by applying strict scrutiny to the parents' claim, the Alfonso court implicitly recognized the parents' liberty interest as fundamental. Only those state actions that impede the exercise of a fundamental right must withstand such scrutiny. ${ }^{72}$ By reviewing the program before it under this standard, the Alfonso court suggested that New York's program burdened such a right. The court thus demonstrated, although it did not explicitly state, that it viewed parental guidance in the sexual development of one's child to be a fundamental right.

Second, in applying strict scrutiny, the Alfonso court found that the program at issue unjustifiably intruded upon the parents' liberty interest. ${ }^{73}$ In so doing, the court distinguished Doe $v$ Irwin-an earlier case holding that condom distribution by nonschool public clinics did not burden parental liberty interests $^{74}$ - on the ground that the distribution programs in Doe were not compulsory. ${ }^{75}$ The Alfonso court explained that since the Doe parents were not obligated by law to send their children to public clinics, it was perfectly logical to find no compulsion in that case. ${ }^{76}$ In contrast, the New York parents were obligated by law-that is, under state compulsion-to send their children to school. ${ }^{77}$ The Alfonso court elaborated that merely forcing parents to send their children into an environment where they would be "exposed to ideas or a point of view with which they disagree or find offensive" would not constitute an intrusion on parental liberty. ${ }^{78}$ Requiring parents to send their children into "an environment where they had unrestricted access to free contraceptives" and where the school itself offered "the means for

70 Id at 265.

71 Id at 267-68 (holding that mere exposure to disagreeable ideas does not burden freedom of religion). See also Mozert $v$ Hawkins County Board of Education, 827 F2d 1058, 1065 (6th Cir 1987) (holding that merely requiring children to read materials offensive to their religion is not unconstitutional burden on free exercise).

${ }_{72}$ See Rotunda and Nowak, 2 Treatise on Constitutional Law $\$ 15.7$ at 434 (cited in note 9).

\footnotetext{
${ }^{73}$ Alfonso, 606 NYS2d at 266-67.

${ }^{74} 615$ F2d 1162, 1168 (6th Cir 1980). See Section II.B.2.

75 Alfonso, 606 NYS2d at 266.

76 Id.

77 Id.

${ }^{78}$ Id.
} 
students to engage in sexual activity at lower risk," however, did. $^{79}$

Having found an intrusion, the court then explored whether, as required by strict scrutiny, that intrusion was justified as necessary to further a compelling state interest. ${ }^{80}$ Because minors could obtain condoms in nonschool clinics without their parents' knowledge, the court held that blocking parental involvement in the school distribution plan was not necessary to meet the state's compelling interest in preventing AIDS, and, therefore, the intrusion on parental rights was unwarranted. ${ }^{81}$ As a result, the school would (at a minimum) have to implement an opt-out provision to continue the program. ${ }^{82}$

In contrast, the Massachusetts Supreme Judicial Court held in Curtis that school condom-distribution programs in which parents have no control over their children's participation are constitutional. ${ }^{83}$ The court agreed with Alfonso that parents possess a fundamental Fourteenth Amendment liberty interest in directing their children's upbringing, ${ }^{84}$ but, unlike Alfonso, found that the condom-distribution program did not interfere with this right. ${ }^{85}$ The Curtis court arrived at this finding by reading into the parental liberty cases a requirement of "coercion." The court thus created a new test, whereby "in order to constitute a constitutional violation, the state action at issue must be coercive or compulsory in nature. Coercion exists where the governmental action is mandatory and provides no outlet for the parents, such as where refusal to participate in a program results in a sanction or expulsion." ${ }^{186}$ Because the students availed themselves of the condoms completely voluntarily, the Curtis court found no coercive burden on parental liberty interests. $^{87}$ The court rejected the argument that the "compulsory setting of public schools" created the necessary coercion, and criticized the Alfonso court for applying this flawed reasoning. ${ }^{88}$

According to the Curtis court, then, because the program was not coercive, it did not burden the parents' liberty interests, and

79 Id.

80 Id.

s1 Id at 266-67.

82 Id.

$83652 \mathrm{NE2d}$ at 585.

84 Id.

85 Id.

86 Id at 586.

87 Id.

\& Id. 
hence required no justification whatsoever. ${ }^{89}$ Therefore, the court held the program, despite its lack of parental control or input, to be constitutional..$^{90}$

With Alfonso and Curtis as the only relevant precedent, it is an open question whether condom-distribution programs must involve parents at all. Moreover, the only court to require parental involvement in school condom-distribution programs did not specify how this involvement should be structured: the Alfonso court mentioned opt-out provisions but was silent about parental consent requirements. ${ }^{91}$ Hence, whether opt-out provisions, standing alone, are constitutional remains unsettled. Commentators and scholars have likewise been silent about whether the two modes of parental involvement have different constitutional implications.

\section{B. Parents' Rights in Other Contexts}

Although only two courts have considered the parental liberty interest in the context of public school condom-distribution programs, analogous lines of precedent-specifically parental challenges to sex education courses and the distribution of condoms outside of school-help illuminate its basis and scope. ${ }^{92}$

89 Id ( $[\mathrm{M}]$ ere exposure to programs offered at school does not amount to unconstitutional interference with parental liberties without the existence of some compulsory aspect to the program.").

90 Id at 586-87.

9t 606 NYS2d at 267.

92 Although minors enjoy some constitutional protections that may limit the ability of both parents and schools to control their education, this Comment does not address them. Such protections include minors' privacy rights, which allow minors wide access to contraceptives and, in extremely specific circumstances, to abortion, both without parental consent. See Carey v Population Services International, 431 US 678, 693 (1977) (contraception); Bellotti v Baird, 443 US 622, 651 (1979) (plurality opinion) (abortion). One may be tempted to use such rights as trump cards to resolve school condom-distribution conflicts, reasoning that if minors can have abortions without parental knowledge, they should be able to receive condoms at schools without parental involvement.

Courts should resist this temptation. The important conflict in condom-distribution cases involves the interests of the parents against the interests of the state, not the parents' interests as against their children's. The balance of interests between parents and children has very little impact on the question at issue: whether the state may constitutionally supersede the liberty interest of parents. Parents clash with the state, not their children, when they challenge school condom-distribution programs. They challenge not that somewhere, somehow their children may obtain condoms, but that the school itself provides them. Objecting to the latter does not directly implicate a minor's right to contraception (assuming, for the sake of argument, that such a right exists) because nonschool clinics and stores remain viable alternative sources. Hence, it is the power of the state, not the rights of children, that merits attention. 


\section{Parental challenges to sex education courses.}

Most in-school condom-distribution programs take place in conjunction with traditional sex education programs. ${ }^{93}$ Although providing condoms is different from providing education, parental challenges to traditional sex education courses have helped define parents' rights to direct and control their children's education. Although these challenges have arisen under the Free Exercise Clause, rather than the Due Process Clause, they suggest some general contours for the ability of parents to influence their children's education under both clauses. Hence, the courts' analyses of challenges to sex education courses shed light on how courts might deal with possible attacks on school condom-distribution programs. ${ }^{94}$

Unfortunately, case law in this area is mixed and underdeveloped. Two main themes, however, do emerge. One line of cases suggests that the Free Exercise Clause requires parents to have final authority over their children's attendance in sex education classes. ${ }^{95}$ According to these cases, such classes cannot be mandatory. Another line of cases, however, suggests that schools can conduct mandatory sex education classes. These courts hold either that exposing children to the content of such classes does not burden parents' free exercise rights, ${ }^{96}$ or that the state's interest justifies such a burden. ${ }^{97}$

The first line of cases suggests that the First Amendment requires that parents make the ultimate decision whether or not their children attend sex education classes. These cases either reject programs lacking opt-out provisions ${ }^{98}$ or approve programs with excusal provisions. ${ }^{99}$ Hence, programs allowing par-

93 See, for example, Alfonso, 606 NYS2d at 261.

94 For other discussions of sex education, see Dutile, Sex, Schools and the Law at 4770 (cited in note 12); Comment, Sex Education: The Constitutional Limits of State Compulsion, 43 S Cal L Rev 548, 565-67 (1970) (an example of the early debate surrounding sex education courses); Sanders, Comment, $61 \mathrm{U}$ Cin L Rev at 1481-88 (cited in note 62).

${ }_{95}$ See, for example, Hobolth $v$ Greenway, 52 Mich App 682, 218 NW2d 98, 99-100 (1974), Valent $v$ New Jersey State Board of Education, 114 NJ Super 63, 274 A2d 832, 840-41 (Ct Ch Div 1971); Medeiros v Kiyosak, 52 Hawaii 436, 478 P2d 314, 317-18 (1970).

${ }_{96}$ See, for example, Citizens for Parental Rights v San Mateo County Bd of Educ., 51 Cal App 3d 1, 124 Cal Rptr 68, 83 (1975).

97 See, for example, Davis v Page, 385 F Supp 395, 404 (D NH 1974).

98 See Hobolth, 218 NW2d at 100 (noting that trial court had ordered parental involvement in the sex education program); Valent, $274 \mathrm{~A} 2 \mathrm{~d}$ at 839-41 (implying that programs lacking excusal provisions are not the sole means of satisfying the state's interest in providing sex education).

${ }_{99}$ See Medeiros, 478 P2d at 316; Citizens for Parental Rights, 124 Cal Rptr at 83. 
ents to make the final decision either do not burden free exercise rights (and hence have no constitutional infirmities), ${ }^{100}$ or burden them so slightly that they are justified. ${ }^{101}$

As illustrated above, most courts contemplate that the First Amendment does require some type of parental involvement in deciding whether or not children attend sex education classes. Some courts, however, disagree. These courts find either that the state's interest in a uniform curriculum justifies the intrusion upon parental rights that accompanies compulsory attendance, ${ }^{102}$ or that mere exposure to the content of such courses is insufficient to allege a free exercise claim. ${ }^{103}$

It is tempting to view condom-distribution programs as merely another aspect of these basic sex education courses and to extend the courts' general sanction of the latter to the former. Because of the distinction between providing information and providing condoms, however, neither line of sex education precedent satisfactorily applies to school condom programs.

In the sex education context, challenges to programs that incorporate parental involvement uniformly fail. The direct application of this precedent would render any condom-distribution program that involved parents constitutional, regardless of the form of that involvement. The application of this precedent, however, would not sufficiently address all of the issues surrounding condom-distribution programs. Under the strict scrutiny that such programs should trigger, ${ }^{104}$ they should be narrowly tailored to meet the state's interest in preventing AIDS and pregnancy. ${ }^{105}$ This line of sex education cases, however, does not address how different forms of parental involvement would impact the analysis of the narrow-tailoring requirement. These cases either find no burden on parents' rights (and hence do not inquire

${ }^{100}$ Medeiros, 478 P2d at 317-18.

${ }^{101}$ Citizens for Parental Rights, $124 \mathrm{Cal}$ Rptr at 83 (noting that "even assuming an infringement for the sake of argument, the incidental burden is justified by the compelling state interest in education").

${ }^{102}$ See, for example, Davis, 385 F Supp at 404 ("The state has a paramount and recognized duty to provide for the health, welfare, and safety of its citizens. The health course, which is secular in nature and purpose, is a proper means by which the state can discharge this duty.").

${ }^{103}$ Id ("[T] $]$ ho most [the plaintiffs] have shown is that they find the health course to be 'distasteful.' This allegation without more does not invoke the broad mantle of protection afforded by the First Amendment.").

104 See text accompanying notes 126-45.

${ }_{105}$ Rotunda and Nowak, 2 Treatise on Constitutional Law $\$ 15.4$ at 402 (cited in note 9). 
into the state's interest), ${ }^{106}$ or find a compelling interest but skip the narrow-tailoring issue. ${ }^{107}$ For today's courts to analyze correctly the constitutionality of school condom-distribution programs under strict scrutiny, they must determine whether such programs are narrowly tailored-an analysis that entails an examination of the differences between opt-out provisions and prior-consent requirements.

The analysis of the courts allowing compulsory sex education classes even absent parental involvement likewise fails to address all the issues attendant to condom distribution. In these cases, parental challenges to programs blocking their involvement fail if courts either find mere exposure to distasteful ideas insufficient to constitute a free exercise burden or find that this burden is outweighed by the state's interest in uniformly educating all children about sexuality. Under this reasoning, parental challenges to condom-distribution programs lacking parental involvement would fail if courts viewed access to condoms the same way they view exposure to information about sex. Because the two are quite different, however, courts should find that school condom-distribution programs do burden parental rights and that this burden is not justified by the same interest that justifies sex education courses. Courts should thus analyze condom-distribution programs separately in order to determine if other, noneducational interests may justify the burdens they impose.

First, courts should recognize that condom-distribution programs, unlike mandatory sex education classes, burden parental liberty interests. Unlike purely informational classes, condomdistribution programs implicitly approve of, and may even encourage, sexual activity. Mandatory school attendance laws thus force parents to send children into an environment that may encourage disobedience, and this should be viewed as a burden.

The basic difference between the two types of programs is that between providing factual information and facilitating action. In the Establishment Clause context, for example, the Court distinguishes between teaching students about religion and facilitating its exercise via school prayer or bible reading. ${ }^{108}$ The

${ }^{106}$ See, for example, Medeiros, 478 P2d at 317-18.

107 See, for example, Citizens for Parental Rights, 124 Cal Rptr at 82-83 (recognizing a "compelling state interest" in sex education but not analyzing the relation between the program's structure and the state's interest).

${ }_{108}$ See, for example, School District of Abington Township v Schempp, 374 US 203, 222-24 (1963). 
Alfonso court recognized a similar distinction in the area of sex education, noting that:

[T] he condom availability component of respondents' distribution program creates an entirely different situation. Students are not just exposed to talk or literature on the subject of sexual behavior; the school offers the means for students to engage in sexual activity at a lower risk of pregnancy and contracting sexually transmitted diseases. ${ }^{109}$

Providing condoms is unlike providing information about sex because the former may lead students to infer approval of sexual activity at a young age. ${ }^{110}$ Students (and parents) can perceive condom-distribution programs as tacitly approving, and even encouraging, sexual activity. ${ }^{111}$

Thus, the maxim that "mere exposure to distasteful ideas is not a free exercise burden,"112 perhaps plausible in the context of sex education, is inapplicable to condom-distribution programs. Parents challenging such programs do not merely object to the fact that their children are exposed to distasteful ideas. Rather, parents feel that the state's intrusion stems from its requirement, via compulsory school attendance laws, that they send their children to an environment where the parens patriae encourages their children to disobey them. Hence, condom-distribution programs, unlike sex education classes, burden the rights of parents because of the messages of approval and the actual facilitation that such programs entail.

109606 NYS2d at 266. A similar distinction between ideas and acts was made in Mozert $v$ Hawkins County Board of Education, albeit in the free exercise context. 827 F2d 1058, 1065 (6th Cir 1987) ("The requirement that students read the assigned materials ... in the absence of a showing that this participation entailed ... performance or non-performance of a religious exercise ... does not place an unconstitutional burden on the students' free exercise of religion.").

110 At a Montgomery County School Board meeting concerning the implementation of a condom-distribution program, a seventeen-year-old individual told the board "that distributing condoms takes authority away from parents and puts schools in a position of condoning premarital sex.... Deep down, young people want to be led and shown what is right,' he said to a standing ovation." Arlo Wagner, Condoms in health rooms decried, Wash Times C6, C6 (June 29, 1994).

111 The Supreme Court has recognized that not only younger children but also teenagers may have trouble differentiating between a school merely exposing them to an idea and a school sanctioning that idea. This recognition underlies much of the Court's Establishment Clause jurisprudence. See, for example, Lee $v$ Weisman, 505 US 577, 592 (1992) ("[T]here are heightened concerns with protecting freedom of conscience from subtle coercive pressure in the elementary and secondary public schools.").

132 See Davis, 385 F Supp at 404. 
Second, courts should find that the interest that justifies sex education courses does not justify condom-distribution programs. The two serve related, but markedly different, goals. Sex education courses primarily aim to educate children about sex and their bodies; the prevention of teen pregnancy, AIDS, and other sexually transmitted diseases is a mere byproduct of this education. Condom-distribution programs, by contrast, seek to serve solely a preventive interest by providing the means for those who are sexually active to be so safely.

Sex education serves the state's interest in uniformly educating all children about sexuality because it informs children about changes occurring in their bodies and the new responsibilities and opportunities these changes present. It is this educational interest that justifies the burdens, if any, of sex education programs. Because the courts' approval of sex education is based on the state's compelling educational interest, automatically extending this approval to condom programs ignores the fact that condom programs serve no such educational interest. Instead, they seek to serve the distinct interest of preventing AIDS and teen pregnancy. Whether they further this interest, and whether that interest justifies the attendant burden on parental liberty, requires an analysis separate from that of sex education courses.

Thus, sex education precedent is inapposite to in-school condom-distribution programs for two reasons. First, it ignores the distinction between merely teaching children about sex and implicitly encouraging and facilitating sexual activity. This encouragement and facilitation, unlike mere education, burdens the liberty interests of parents who object to the programs, by creating an environment-into which the parents are forced by law to send their children-that these parents feel is hostile to their beliefs. Second, the justifications for any burdens inherent in mandatory sex education programs fail to justify the burdens placed on parental liberty by condom-distribution programs that circumvent parental authority.

2. Parental challenges to the distribution of condoms to minors in nonschool settings.

Though there is little dispute that nonschool public clinics may distribute contraceptives to minors without parental notification, ${ }^{113}$ the constitutional analysis of such distribution is differ- 
ent than in the school clinic context. In Doe, for example, concerned parents objected to this practice, alleging that condom distribution by nonschool clinics violated their parental liberty interests. ${ }^{114}$ The Sixth Circuit disagreed, holding that since Michigan "imposed no compulsory requirements or prohibitions which affect the rights of plaintiffs ... [but] merely established a voluntary birth control clinic," it had not interfered with the parents' liberty interests. ${ }^{115}$ Since there was no interference with parental constitutional rights, the court did not examine whether the state interest was "compelling." This implied that had the court found an interference with plaintiffs' parental rights, it would have applied strict scrutiny to judge the constitutionality of that interference. ${ }^{117}$ Since the court found no infringement, however, it did not apply any test at all.

If nonschool clinics may distribute condoms to minors who seek them out, one might think school clinics should also have the same ability. Indeed, as the Curtis court pointed out, children are required to go to school but not to go to clinics within those schools. ${ }^{118}$ This reasoning, however, should not control the analysis. As the Alfonso court noted, the distinction between the school itself and a school-based clinic is extremely tenuous. ${ }^{119}$

ment in the nonschool clinic context have fared poorly. Case law suggests that the federal government may not require federally funded family planning clinics to notify parents when minor children seek birth control devices. In these cases, courts hold that notification requirements would inhibit teens from seeking medical supervision of such services, thus thwarting the congressional intent behind the establishment of such clinics. New York $v$ Schweiker, 557 F Supp 354, 361 (S D NY 1983); Planned Parenthood Federation of America, Inc. $v$ Schweiker, 559 F Supp 658, 668 (D DC), aff'd as Planned Parenthood Federation of America v Heckler, 712 F2d 650 (DC Cir 1983). For more detailed treatments of these cases, see Brenda D. Hofman, Note, The Squeal Rule: Statutory Resolution and Constitutional Implications-Burdening the Minor's Right of Privacy, 1984 Duke L J 1325, 1332-37; Linda Himmelfarb, The "Squeal Rule" Revisited, 51 Brooklyn L Rev 704 (1985). See also Boumil, 18 Seton Hall $L$ Rev at 360-64 (cited in note 65).

114 615 F2d at 1166-67.

115 Id at 1168 (distinguishing Pierce, Meyer, and Prince because "[i]n each of the Supreme Court cases the state was either requiring or prohibiting some activity").

116 Id at 1169.

117 Id.

$118652 \mathrm{NE} 2 \mathrm{~d}$ at 586.

119 The Alfonso court stated the point thus:

Parents must send their children to school .... This is the key distinction between the situation these petitioners face and that faced by the parents who sued in Doe $v$. Irwin. In Doe the plaintiffs were attempting to enjoin the distribution of contraceptive devices to their children at a public clinic. The clinic, however, was not inside a school or other building where the parents were obliged by law to send their children. Consequently, in Doe there was no State compulsion on parents to send their children into an environment where they had unrestricted access to free contracep- 
States intrude on parental liberty when schools distribute condoms because parents are required by law to send their children to school and concurrently to cede some of their authority to these schools. By contrast, minors who go to other public clinics do so completely voluntarily, without the accompanying compelled transfer of parental authority to the state. Parents objecting to school condom distribution do so because they are forced to send their children to an antithetical environment where the parens patriae encourages their children to obtain condoms, regardless of the parents' desires. ${ }^{120}$ Indeed, proponents of school programs cite the circumvention of parents as one justification for such programs. ${ }^{121}$

The voluntary nature of the school condom-distribution programs does not shield them from constitutional challenge, for the parents' role remains involuntary. ${ }^{122}$ Parents must still send their children into an environment that they perceive as directly contradicting what they attempt to teach at home, and implicitly encouraging disobedience. This facilitating function, not the possibility that their children may receive condoms, is the burden.

Two other factors reinforce the notion that distribution in school clinics, in contrast to nonschool clinics, burdens parental rights. First, the state requires children to go to school in part so that it may instill certain values in them, ${ }^{123}$ whereas it establishes public health clinics not to instill values but to provide

tives, which is precisely what the petitioners in the instant matter must do.

606 NYS2d at 266 (citation omitted).

${ }_{120}$ Although wealthy parents could avoid this by sending their children to private schools, most families cannot afford that option. Moreover, in this context, private schooling is the equivalent of an opt-out provision, just a more expensive one.

121 For proponents of condom-distribution programs who expect parents to be either hostile or indifferent to their children's sexual activity, see Pratt, Superintendent Balks, Wash Post Md Weekly at 7 (cited in note 14) (quoting Jerry Shier, chairman of Montgomery Medical Advisory Committee: "If we knew all parents would sit down, discuss and support their children, it would be less of an issue to deal with it in the schools."); Ingfei Chen, Condom Giveaway Starts in S.F., SF Chronicle A13 (May 5, 1992) (available in LEXIS) (quoting seventeen-year-old student: "It should have been available a lot sooner .... A lot of these kids don't feel comfortable talking about it with their parents."); Buckley, Sex Education's Tough Question, Wash Post at D3 (cited in note 12) (quoting Eugene Sussman, chairman of Montgomery Medical Advisory Committee, arguing for the programs because "a lot of parents don't know that their teenagers are sexually active and are going from one partner to another").

${ }_{122}$ See Alfonso, 606 NYS2d at 265-66 ("The minority points to the fact that student participation ... is wholly voluntary .... However, these factors do not constitute proof that the petitioners are not being forced to surrender a parenting right.").

${ }^{123}$ See, for example, Amy Gutmann, Democratic Education 42-43 (Princeton 1987) (describing how the critical function of schools is to instill democratic values in students). 
medical facilities to the poor. Schools target children as children; public health clinics provide programs for people of all ages. Hence, for children, activities in school carry with them a greater implicit state sanction than activities carried on in other state institutions. This purposeful indoctrination necessarily interferes more with what parents teach at home than do similar messages from voluntarily attended nonschool programs. ${ }^{124}$ Finally, students generally feel greater peer pressure at school than in any other setting. Giving out condoms at school adds to this peer pressure by insinuating that not only do their peers expect teens to be sexually active, but so do their teachers. ${ }^{125}$

Together, these factors demonstrate that, unlike their nonschool counterparts, in-school condom-distribution programs necessarily interfere with parental liberty rights. Thus, such programs cannot be summarily validated under the Doe reasoning that noncompulsory state-sponsored activity does not infringe parental rights.

\section{A PRoposed FrameWORK For ANALYZING PARENTAL LIBERTY AND SCHOOL CONDOM-DISTRIBUTION PROGRAMS}

\section{A. Parental Liberty and Strict Scrutiny}

The Supreme Court has never explicitly stated that parental liberty claims should be reviewed under the strict scrutiny of modern due process analysis. ${ }^{126}$ The trilogy of cases establishing the parental liberty interest used the "reasonable relation" language common to their era. ${ }^{127}$ Later cases mixed free exercise and parental liberty claims. ${ }^{128}$ In contrast, lower federal and state courts have explicitly held the parental liberty interest to be fundamental and deserving of strict scrutiny. To these courts,

${ }^{124}$ One commentator notes that "[t]he atmosphere of the public school intensifies the coercion of its teaching. Most governmental messages must compete with other messages and can be ignored .... In public schools, however, not only must children listen to school doctrine exclusively, but they also must learn and accept that doctrine." George W. Dent, Jr., Religious Children, Secular Schools, 61 S Cal L Rev 864, 892 (1988).

${ }^{125}$ When schools convey such messages, it is not surprising that many teens feel that "adult society fully expect[s] them to be sexually involved." Laurie Goodstein, Saying No to Teen Sex in No Uncertain Terms, Wash Post A1, A4 (July 30, 1994) (quoting Richard Ross, Youth Minister at Tulip Grove Baptist Church).

${ }^{126}$ See Daniel J. Rose, Note, Compulsory Education and Parent Rights: A Judicial Framework of Analysis, 30 BC L Rev 861, 880-81 (1989).

${ }^{127}$ See text accompanying notes 16-29, 43.

${ }^{128}$ See text accompanying notes $30-40,44$. 
however, the parental liberty interest includes only certain parental activity. ${ }^{129}$

Despite the Supreme Court's silence and the lower courts' inconsistency, several factors suggest that influencing the sexual decisions of one's child is part of the constitutionally protected parental liberty interest and that infringements on this interest warrant review under the tough standard of strict scrutiny. Under the strict scrutiny standard, state infringements of a fundamental right must be "necessary" and "narrowly tailored" to meet a compelling state interest. ${ }^{130}$

The trilogy of cases that established the parental liberty interest all explicitly grounded their holdings in the Fourteenth Amendment Due Process Clause because they viewed parental liberty as "essential to the orderly pursuit of happiness by free men."131 Today, a select group of similar liberties, not mentioned in the Constitution but which protect "basic values 'implicit in the concept of ordered liberty, ${ }^{\prime \prime 132}$ routinely merit the protection of strict scrutiny as fundamental rights under the doctrine of substantive due process. ${ }^{133}$ The right to marry, to travel, and to vote are all examples of such "basic values" meriting the protection of modern strict scrutiny. ${ }^{134}$ Because parental liberty is likewise a basic value and an "enduring American tradition,"135 it should be deemed fundamental and accorded similar protection. The Court's repeated acknowledgment of the importance of parental guidance suggests that it may be amenable to

129 Compare Murphy v Arkansas, 852 F2d 1039, 1043 (8th Cir 1988) (refusing to apply strict scrutiny analysis to a claim that parents could educate their children through home schooling free of any state regulation whatsoever), with Doe, 615 F2d at 1167-69 (characterizing parental liberty rights as fundamental and implying that strict scrutiny would be applied if those rights were burdened).

${ }^{130}$ Rotunda and Nowak, 2 Treatise on Constitutional Law $\S 15.4$ at 402 (cited in note 9). Such infringements fit this definition only when there is no less restrictive alternative available to the state. See also Ware $v$ Valley Stream High School District, 75 NY2d 114, 551 NYS2d 167, 176 (1989) (noting that in strict scrutiny cases involving religious free exercise, compelling state interests must be pursued "by the least restrictive means").

${ }^{131}$ Meyer, 262 US at 399.

132 Griswold v Connecticut, 381 US 479, 500 (1965) (Harlan concurring), quoting Palko $v$ Connecticut, 302 US 319, 325 (1937).

${ }^{133}$ For judicial explorations of fundamental rights and substantive due process, see Planned Parenthood v Casey, 505 US 833, 846-49 (1992); Bowers v Hardwick, 478 US 186, 190-96 (1986); Reno v Flores, 507 US 292, 302 (1993); Michael H. $v$ Gerald D., 491 US $110,122-23$ (1989).

${ }^{134}$ Loving $v$ Virginia, 388 US 1, 12 (1967) (right to marry); Shapiro v Thompson, 394 US 618, 629-31 (1969) (right to interstate travel); Harper $v$ Virginia State Board of Elections, 383 US 663, 670 (1966) (right to vote).

135 Yoder, 406 US at 232. 
this argument. ${ }^{136}$ Moreover, the Court frequently includes the parental liberty interest in lists of rights protected by the Fourteenth Amendment alongside rights the Court has explicitly deemed fundamental, ${ }^{137}$ suggesting that it sees little or no difference among these rights. Because the Court thus currently seems to view these rights as equals, it should explicitly recognize the parental liberty interest as fundamental. By doing so, it would make express what its cases clearly imply: intrusions on the parental liberty interest merit the strong protection of strict scrutiny. ${ }^{138}$

Further, the Supreme Court has enunciated certain "privacy" rights as fundamental, thereby subjecting infringements on them to strict scrutiny. ${ }^{139}$ These privacy rights include basic familial rights (for example, decisions regarding procreation, marriage, and living arrangements) that are strikingly similar to parental liberty interests. Although uncertainty exists as to whether privacy rights include parental rights or whether the two are related but doctrinally separate, ${ }^{\mathrm{I} 40}$ both are clearly grounded in the Fourteenth Amendment. Indeed, the Court repeatedly cites Pierce and $M e y e r$ in its privacy decisions, further suggesting that the two rights enjoy similar constitutional protections. ${ }^{141}$

${ }^{135}$ See note 46. See also Prince, 321 US at 166 ("It is cardinal with us that the custo$\mathrm{dy}$, care and nurture of the child reside first in the parents, whose primary function and freedom include preparation for obligations the state can neither supply nor hinder."); Yoder, 406 US at 232 ("The history and culture of Western civilization reflect a strong tradition of parental concern for the nurture and upbringing of their children. This primary role of the parents in the upbringing of their children is now established beyond debate as an enduring American tradition.").

137 See, for example, Casey, 505 US at 851; Bellotti $v$ Baird, 443 US 622, 637, 639 n 18 (1979) (plurality opinion); Roe $v$ Wade, 410 US 113, 152-53 (1973); Moore $v$ City of East Cleveland, 431 US 494, 499 (1977).

${ }^{133}$ See Rotunda and Nowak, 2 Treatise on Constitutional Law $\S 15.7$ at 434-36 (cited in note 9 ).

120 See, for example, Roe, 410 US at 155; Carey v Population Services International, 431 US 678, 686 (1977).

${ }^{140}$ Compare Rose, Note, $30 \mathrm{BC}$ L Rev at 881 (cited in note 126) (arguing that there is little difference between privacy analysis and parental liberty), and Runyon v McCrary, 427 US 160, 178 n 15 (1976) ('The Meyer-Pierce-Yoder 'parental right' and the privacy right ... may be no more than verbal variations of a single constitutional right."), with Francis Barry McCarthy, The Confused Constitutional Status and Meaning of Parental Rights, 22 Ga L Rev 975, 985-1006 (1988) (exploring various characterizations of parental rights), and Anne C. Dailey, Constitutional Privacy and the Just Family, 67 Tulane L Rev 955, 986 (1993) ("Parental rights are not simply a modified version of the individual right of privacy.").

${ }_{141}$ See, for example, Roe, 410 US at 152-53 (in dictum, treating family relationships and child rearing as fundamental rights); Griswold, 381 US at 483 (reaffirming "the principle of the Pierce and the Meyer cases"). 
Last, influence over the sexual decisions of one's child resembles other parental activities that lower courts have included in the parental liberty interest-activities that states' attempts to usurp warrant strict scrutiny. Generally, parental activities that would either completely exclude the state from some aspect of their children's education or give parents ultimate control over all aspects of traditional public school curricula are not part of the protected interest. ${ }^{142}$ Conversely, activities that allow parents to remain involved when the state assumes responsibilities traditionally left to the family will be included in the liberty interest. ${ }^{143}$ Hence, these courts apply strict scrutiny to some, but not all, state regulations impeding parental activities.

Courts should view parental consent mechanisms in school condom programs as falling within the second category of activities and, therefore, as protected by the parental liberty interest. Parents asking for such involvement when schools distribute condoms do not seek to block the state from exerting any influence over a child's sexual decisions by, for example, contesting sex education classes or condom distribution at other clinics. Nor do they seek control over all aspects of traditional school curricula, for such active school involvement in children's sex lives is a relatively recent phenomenon. ${ }^{144}$ Instead, they ask merely that the state share authority in one very slim area-whether or not their children may obtain condoms at school. Indeed, lower courts

${ }_{142}$ See People v Bennett, 442 Mich 316, 501 NW2d 106, 111-12 (1993) (refusing to cast as fundamental the right to home school one's child completely free of any state regulation whatsoever); Herndon v Chapel Hill-Carrboro City Board of Education, 899 F Supp $1443,1450-51$ (M D NC 1995) (holding that parents have no fundamental right "to exert pre-emptive control over the curriculum of public schools" in the context of challenges to a community service requirement). Courts base such exclusions on overly narrow readings of Pierce and Yoder. By focusing solely on the religious aspects of the two cases, courts conclude (wrongly) that only parental objections with religious components merit strict scrutiny. See Bennett, 501 NW2d at 111-13; Herndon, 899 F Supp at 1450-51. As this Comment demonstrates in Section I, however, the Pierce Court never mentioned free exercise rights, and the Yoder Court did not foreclose the application of strict scrutiny to secular parental objections via the Fourteenth Amendment. See text accompanying notes 36-40.

143 See, for example, Michael v Hertzler, 900 P2d 1144, 1145 (Wyo 1995) (holding parents' right to determine who visits their child to be fundamental).

144 What is key here is that the school involvement in this new area can likely contradict traditional parental teachings in that area. The community service programs in Herndon, 899 F Supp at 1443, should thus be viewed as "traditional." Schools have long emphasized the importance of volunteering and giving, and such emphasis is unlikely to undermine parental attempts to influence their children in a sensitive and private area. Community-mindedness is a far cry from sexual activity. 
have applied a strict scrutiny-type analysis to such programs. ${ }^{145}$

Because of its Fourteenth Amendment grounding and its similarity to privacy rights and religious free exercise rights, parental liberty merits the strong protection of strict scrutiny. This liberty should include actions by parents by which they merely seek to share with the state control over their children's sexual development. School condom programs thus merit review under a strict scrutiny standard.

\section{B. Prior-Consent Requirements, Opt-Out Provisions, and Par- ents' Rights}

As demonstrated above, school condom-distribution programs, in contrast to nonschool clinic programs, necessarily impair parents' Fourteenth Amendment liberty interests, thus triggering strict scrutiny review. ${ }^{146}$ Only prior-consent requirements, and not opt-out provisions, can withstand such scrutiny. Strict scrutiny requires that a program not only involve a compelling state interest but also that it be "necessary" and "narrowly tailored"-that is, the least restrictive means possible-to meet that interest. ${ }^{147}$ In the specific context of condom distribution in public schools, the question thus becomes: What method of distributing condoms to minors to further the state's compelling interest in combating AIDS $^{148}$ is least restrictive of parents' Fourteenth Amendment liberty interests? This Section demonstrates that while programs that require prior consent and programs containing opt-out provisions both pursue the state's com-

${ }^{445}$ See, for example, Alfonso, 606 NYS2d at 266.

146 See text accompanying notes 139-45.

147 Rotunda and Nowak, 2 Treatise on Constitutional Law $\S 15.4$ at 402 (cited in note 9). Although not every statement of the strict scrutiny test explicitly states that the "least restrictive means" possible is required, this is in effect what courts look for when they ask whether an intrusion is narrowly tailored. That courts use different rhetoric does not change the substance of the test. See Craig R. Ducat and Harold W. Chase, Constitutional Interpretation 94 (West 5 th ed 1992). See also Ware $v$ Valley Stream High School District, 75 NY2d 114, 551 NYS2d 167, 176 (1989) (noting that in cases involving religious free exercise, compelling state interests must be pursued "by the least restrictive means"); Rose, Note, $30 \mathrm{BC} \mathrm{L} \mathrm{Rev} \mathrm{at} \mathrm{897,} 883$ (cited in note 126) (arguing that "parents' rights to guide the education of their children" are fundamental rights deserving strict scrutiny and that "[u]nder such an analysis, a state may not impinge on such a right unless the action it is taking is the least restrictive alternative to achieving a compelling state interest").

148 There is no doubt that preventing AIDS is a compelling state interest. See Alfonso, 606 NYS2d at 266. Accordingly, this Comment focuses on the latter part of the strict scrutiny test, the means used to meet that interest. 
pelling interest in preventing AIDS, the former are the least restrictive means to that end.

Because the burden posed by opt-out clauses is inherently greater than that of prior-consent requirements, opt-out clauses fail to meet the "least restrictive means" portion of the strict scrutiny standard. Opt-out provisions force concerned parents to act affirmatively to regain their natural legal authority. In contrast, consent requirements leave this authority with the parents until they knowingly and voluntarily delegate it to school offcials. ${ }^{149}$

Legislatures and courts have recognized the strong "principle of express prior consent" in other areas. ${ }^{150}$ For example, in the school context, officials must obtain parental consent before performing even routine medical services such as providing aspirin and before including children in certain activities such as field trips and contact sports. ${ }^{151}$ Consent, then, is required in special situations ${ }^{152}$ so that parents knowingly and voluntarily cede their authority to the school.

149 Parents challenging school condom-distribution programs as violating their right to consent to medical services recognized this distinction, explaining that:

The requirements of prior parental consent (opt-in) and parental veto (opt-out) are functionally and procedurally different. Parental consent is more stringent, more protective of the rights at stake because it requires the entity seeking consent to wait until consent is affirmatively given. For example, if a parent does not act, consent is not given. Opt-out, on the other hand, allows the entity seeking approval to proceed until the parent actually vetoes their child's participation. For example, if a parent does not act, consent is assumed.

Parents United for Better Schools, Inc. v School Dist. of Philadelphia Bd of Educ., $166 \mathrm{~Pa}$ Commw 462, 646 A2d 689, 691 (1994).

${ }_{150}$ See, for example, id at 692 (holding that the common law right of parents to consent to the provision of medical services gives parents standing to challenge condomdistribution program opt-out provisions as violating that right). Legislatures often implicitly recognize this distinction. For example, in Pennsylvania, minors must secure consent before getting tattoos, donating blood, driving a car, getting a marriage license, or waiving their Miranda rights. Id.

151 See, for example, William D. Valente, 2 Education Law: Public and Private $§ 19.23$ at 212 (West 1985) (acknowledging "[t]he common school practice of obtaining written parental consents or waivers ... for designated [school] (e.g. field trips) activities"); Cal Educ Code Ann $\S 49302$ (West 1993) (requiring parental consent before pupils can be transported).

${ }_{152}$ Virginia Governor George Allen considers the mere provision of sex education courses such a special situation. Thus, he has proposed replacing Virginia's current optout provisions with prior parental-consent requirements. Virginia parents perceive a distinction between the two types of parental liberty safeguards. One parent explained, "[i]t ought to be something that parents choose, rather than having to feel obligated to pull out of." Michael D. Shear, Some Parents Back Plan on Sex-Ed, Wash Post Va Weekly 1, 7 (Dec 8, 1994). 
Given that prior-consent requirements are less burdensome than opt-out clauses, the question whether programs entailing the former adequately further the state's interest in preventing AIDS remains to be addressed. As demonstrated in the following example, programs with prior-consent requirements do in fact serve that end as well as programs with opt-out clauses.

To illustrate the difference between the two programs, imagine a high school with one thousand students. Five hundred sets of parents would consent to condom distribution to their teenagers, three hundred would not, and two hundred are indifferent. Imagine that the eight hundred sets of parents with definite opinions took whatever action the state required, by either signing a consent form or an opt-out form to evidence their desires. The indifferent two hundred, however, do nothing under either regime.

In a program with prior-consent requirements, only five hundred students receive condoms. However, the school has not infringed on the parental rights of those five hundred sets of parents giving their consent. These parents are no worse off than before the program's implementation. They merely voluntarily delegated some authority to the state. Nor does this program burden the rights of the three hundred sets of nonconsenting parents, since these parents are not required to act affirmatively to maintain their authority.

In a program with an opt-out provision, seven hundred students receive condoms. Note, however, that the three hundred sets of nonconsenting parents were forced to act affirmatively to assert their rights, since the presumption of responsibility is shifted from the parents to the state.

Thus, the debate boils down to the extent of the state's interest in providing condoms to the students of the indifferent parents: In order to reach those two hundred students, is the state's interest strong enough to justify the burdens on the three hundred sets of concerned parents? Several factors suggest that the effect of prior-consent programs on the children of the indifferent parents would be minimal. This also suggests that the more intrusive opt-out programs might not be necessary to achieve the state's goal. ${ }^{153}$

153 Many of these arguments are also made by commentators examining the more general question whether schools must involve parents at all. See Boumil, 18 Seton Hall L Rev at 374-77 (cited in note 65). Boumil argues, for example, that clinics dispensing contraceptives without parental notification violate the parents' rights (a) by enabling 
First, the state may still teach about condoms in sex education classes and distribute them at nonschool public health clinics. ${ }^{154}$ One anecdotal account reported eight such clinics within a fourteen-block radius of one urban public high school. ${ }^{155}$ Moreover, students may purchase condoms cheaply at any drug store. Second, evidence does not support the effectiveness of school condom-distribution programs in reducing pregnancy and AIDS, ${ }^{156}$ and it has been pointed out that availability is not determinative of contraceptive use. ${ }^{157}$ Third, the threat of AIDS is not so great as to give the state carte blanche to intrude on parental liberty. Analogous risks have not justified unlimited intrusion upon similar rights. ${ }^{158}$ Fourth, underage consensual sex is still illegal in most states. ${ }^{159}$ Implicitly encouraging children to do what a state has statutorily disapproved of seems to undermine the state's interest. In effect, the state is saying that its interest is having teens break laws safely. ${ }^{160}$ Finally, the lack of concern of these indifferent parents does not necessitate a burden on those parents who do care. ${ }^{161}$ That is, the lack of interest of

minors to circumvent parental involvement; (b) by depriving parents of the chance to add to, influence, or counteract the clinic's advice; and (c) by encouraging some parents to avoid educating their children about sex as that task will be seen as the state's responsibility. Id at 375 .

${ }_{154}$ See Section II.B.2.

${ }_{155}$ Douglas J. Besharov and Karen N. Gardiner, Teen Sex: truth and consequences, Orlando Sentinel G1, G5 (Feb 21, 1993).

156 Kay Coles James, Clinton's 'condom CEO' nomination, Wash Times G3, G3 (July 14, 1993) (reporting that "[a]ccording to Douglas Kirby, consultant for the National Center for Population Options, an organization that promotes [school-based clinics], the clinics reportedly "had no measurable impact on teen pregnancy rates").

157 Besharov and Gardiner report that "an objective look at the data reveals that availability is not the prime factor in determining contraceptive use. Almost all young people have access to at least one form of contraception." Besharov and Gardiner, Teen Sex, Orlando Sentinel at G5 (cited in note 155) (basing conclusions on 1979 survey by Johns Hopkins School of Hygiene and Public Health that found that more than 75 percent of children between the ages of fifteen and nineteen had received sex education and that 75 percent of those children "remember[ed] being told how to obtain contraception").

${ }^{158}$ Ware, 551 NYS2d at 176 (noting that "[a]s with other grave risks we have faced during the past two centuries, the threat of AIDS cannot summarily obliterate this Nation's fundamental values").

159 See, for example, Ala Code § 13A-6-20 (1995); Cal Penal Code Ann § 261.5 (West 1988 \& Supp 1996); Idaho Code $\S 18-1508$ (1987 \& Supp 1995); Mass Ann Laws ch 265, $\S$ 13B (Law Co-op 1992); W Va Code § 61-8B-5 (1992).

${ }_{160}$ Columnist Mona Charen has noted this ironic twist, writing that "[w]e do not take that attitude toward drugs. If we did, there would be clean needle-distribution programs in the public schools. Instead, we do everything possible to 'scare kids straight' about drugs." Mona Charen, Sex, Lies, And Liberals: N.Y. Curriculum Clash, St. Louis Dispatch 3C, 3C (Mar 4, 1993).

161 To the contrary, the state may have an interest in actively engaging these disinterested parents. One scholar has suggested that children are best served when power over 
some parents (whether a minority or a majority) in their liberty interests does not justify state intrusion upon those interests for all parents. The state's interest in providing condoms to those students whose parents are indifferent is, thus, insufficient to justify the intrusion on the liberty interests of the parents objecting to their children's receipt of condoms.

Only one state interest thus justifies school distribution programs: the state's interest in facilitating condom use by students whose parents have actively consented to such facilitation by the school, while at the same time not facilitating condom use by students whose parents object. To this end, prior-consent requirements best assure that what seems like consent really is consent.

Substantively, prior-consent requirements better assure that consent is the product of open and honest discussion. Such requirements mean that consent comes only after parents have actually considered the issue; with opt-out provisions, consent can be found where the topic has been avoided. Such discussions and requirements thus assure that the state exerts its influence, in this specific context, only where truly welcomed by parents. The state will then cross no constitutional boundaries.

Prior consent requirements thus provide the least restrictive means for the state to meet its interest in AIDS and pregnancy prevention. The inherent presumption of opt-out provisions-that silence means consent-is not only unnecessary to meet the state's interest, but is also more intrusive than the alternative. For this reason, schools that wish to distribute condoms constitutionally should require prior parental consent.

\section{CONCLUSION}

When schools distribute condoms, they risk burdening a long recognized "parental liberty" interest-the Fourteenth Amendment right to direct the upbringing of one's child. Unlike sex education courses and nonschool condom-distribution programs, distributing condoms at public schools necessarily burdens parental liberty interests. Because these interests are rooted in the

them is distributed among parents and the state. Under this rationale, "some matters, most notably those concerning health and education, are too important to the well-being of children and society to be entrusted exclusively to any single entity, the family included." Ira C. Lupu, The Separation of Powers and the Protection of Children, 61 U Chi L Rev 1317, 1320 (1994). Decisions concerning contraception surely count as one such matter; hence the state should attempt to involve the family in contraceptive decisions. Requiring parental involvement in school condom-distribution programs would ensure that the state did not have a monopoly in that area. 
fundamental liberties protected by the Due Process Clause of the Fourteenth Amendment, they should be reviewed under the strict scrutiny standard used for modern Due Process Clause claims. Among other things, strict scrutiny requires school condom-distribution programs to be necessary and narrowly tailored-that is, the least restrictive means possible - to meet the state's interest in preventing AIDS.

Only school condom-distribution programs that require prior parental consent survive this scrutiny. Merely allowing concerned parents to opt out of such programs is insufficient. While opt-out provisions recognize the importance of parental influence, only prior-consent requirements are the least restrictive means of achieving the state's interest in AIDS prevention. In contrast to opt-out provisions, prior-consent requirements respect parental authority as controlling until parents voluntarily delegate it to the state. Hence, the state enters the parental domain only when invited-and the Constitution itself requires this invitation. 